\title{
薬物代謝酵素 Cytochrome P450によるキラル選択的代謝への影響の検討 Study of Stereoselective Metabolism by Drug-metabolizing Enzyme Cytochrome P450
}

\author{
O勝浦 彩, 松尾 智史, 永田 佳子, 金澤 秀子 \\ 共立薬科大学 \\ OAya Katsuura, Satoshi Matsuo, Yoshiko Nagata and Hideko Kanazawa \\ Department of Physical Pharmaceutical Chemistry, Kyoritsu University of Pharmacy
}

\section{1. はじめに}

薬物の体内動態は、吸収、分布、代謝、排泄からなる。薬 物の多くは、肝臟で代謝反応を受けて不活性化される。薬物 代謝には、酸化・還元・抱合などの多くの酵素群が関与して いるが、ヒトの代謝反応の約 $80 \%$ には肝臟のミクロソーム 分画中に存在するCytochrome P450 (CYP) が関与している。薬 物代謝に影響する要因として、遺伝多型や相互作用が挙げら れる。遗伝多型により薬物代謝能に個人差が生じるため、薬 効や副作用の発現頻度に遺伝多型が大きく関与する。薬物代 謝酵素CYPの遺伝多型を解明することは、患者の代謝能などの 体質に応じた「テーラーメード医療」の実現において重要で あり、患者個人に応じた安全かつ有効な薬物治療が可能とな ると考えられる。また、現在市販されている合成医薬品の多 くは光学活性体が存在し、経済的な理由などにより、(S) 体と (R) 体を $1: 1$ で含むラセミ体として投与されている。しかし、 (R) 体と (S) 体では薬物動態や薬理活性が大きく異なることが 知られている。薬理活性においては、どちらか一方は薬理活 性を示すが、もう一方は不活性で目的とする薬理効果に寄与 しないものもある。薬物動態に扔いても、(R)体、(S) 体では 代謝の受け方が異なることもある ${ }^{1.2)}$ 。それだけでなく、人間 や動物の内部環境に悪影響を及ぼす可能性もあるため、キラ 儿選択的代謝の解明は重要であると考えられる。

近年、CYP の遺伝多型に関する研究が進展し、薬効・副作 用発現の個人差との関係が明らかになってきている。CYP2D6 は遺伝的にその代謝能が欠損している PM (Poor Metabol izer) の存在が知られている。日本人では、約 $1.3 \%$ と少ないが、 EM(Extensive Metabolizer) と PM の中間の代謝活性を示す IM(Intermediate Metabolizer) が約 $30 \%$ 存在することが知 られている。CYP の中でも、CYP2D6 は基質となる薬物が多い ため、適正投与において無視できない存在であり、CYP1A2 は 喫煙や食物により誘導されることが知られている。本研究で は、医薬品適正使用のための患者の薬物治療の個別化への応 用を目的として、基質に主にCYP2D6 と CYP1A2 で代謝される ことが知られている抗不整脈薬の mexiletine を用いて CYP2D6 の野生型の CYP2D6*1 と遺伝子变異型の CYP2D6*10、 CYP1A2 の in vitro 代謝実験を行うことでキラル選択的代謝 への影響を検討した。また、CYP1A2 の基質で多くの飲食物・ 搘好品に含まれている caffeine を用いて、相互作用を検討す ることを目的として CYPでの in vitro代謝実験を行った。

\section{2. 実験方法}

リン酸緩衝液中 $(\mathrm{pH7} 7$. 4) に光学活性医薬品である mexiletine と NADPH-generating system を加えてプレインキ ユベーションを行い、薬物代謝酵素 (CYP)を加えて反応を開始 し、インキュベーションを行なった。反応停止後に、遠心分 離を行った。上清の固相抽出後にエバポレーションを行い、 溶離液に溶解し、サンプルとした。コントロールには、CYP の代わりにリン酸緩衝液を用いた。HPLC でカラムには CAPCELL PAK C18 $(250 \times 4.6 \mathrm{~mm}$ I. D. $)$ を用いて代謝物の確認
を行い、CHIRALCEL OD-R $(250 \times 4.6 \mathrm{~mm}$ I. D. $)$ を用いてキラル 分離を行った。また、caffeine は HEPES 緩衝液を用いて mexiletine と同様に反応を行い、CAPCELL PAK C18 (250×

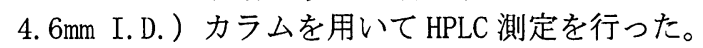

\section{3. 結果・考察}

光学活性医薬品の in vitro代謝実験において、基質に抗不 整脈薬の mexiletine を用い、ODS カラムを用いて分析を行っ た結果、CYP2D6、CYP1A2 どちらを用いた場合にも、代謝物を 確認することができた。また、コントロールとして薬物代謝 酵素を加えていないものを使用して Peak area の減少率をキ ラルカラムを用いて分析を行うことで求めた。CYP2D6を用い た場合、（R）体の方が代謝率が大きくなるとういう結果が得 られた。この結果より、mexiletine の CYP2D6による代謝は、 (R) - mexiletine に立体選択的であることが確認できた。同様 に、CYP1A2 を用いて代謝実験を行った場合も、(R) 体の方が (S) 体よりも代謝率が大きく、mexiletine の CYP1A2 による代 謝は $(\mathrm{R})$ - mexiletineに立体選択的であることが確認できた。 これらの結果より、mexiletine の薬物代謝酵素(CYP)による 代謝は、CYP2D6、CYP1A2 のどちらの場合にも、(R)-mexiletine の方が選択的に代謝されることが確認された。また、野生型

(正常) の CYP2D6*1 と変異型（代謝能低下）の CYP2D6*10 を用いて代謝を行った結果、代謝率に変化が見られ、(R)体、 (S) 体関わらず、野生型である CYP2D6*1 のほうが、变異型で 代謝能の低下した CYP2D $6 * 10$ より代謝率が大きくなるという 結果が得られた。これらの結果より、Mexiletine の CYP2D6 による代謝は遺伝多型の影響を受けることが示唆される。 CYP2D6 は有効治療領域の狭い精神科領域や心血管領域の薬 物の代謝に多く関わる分子種であるため、患者個人への適正 投与を目的とした光学活性医薬品のキラル選択的代能の解析 は重要であると考えられる。

Caffeine をCYP を用いて in vitro代謝実験を行い、コン トロールとして薬物代謝酵素を加えていないものを使用して ODS カラムを用いて分析を行った結果、代謝物を確認するこ とができた。この結果より、caffeineもCYPによる代謝を受 け、代謝物を生成することが確認できた。飲食物や嗜好品な どに caffeine は多く含まれているため、同じ CYP の分子種で 代謝される薬物と同時に服用したときにCYP の競合が起こり、 薬物相互作用の原因となることもある。そのため、caffeine と同じ CYP の分子種で代謝される薬物を服用したときの体内 動態の解析に応用できると考えられる。

\section{4. 参考文献}

1) H. Kanazawa, A. Okada, M. Higaki, H. Yokota, S. Okubo, F. Mashige, K. Nakahara, J. Pharm. Biomed. Anal. 30 (2003) 1817-1824.

2) H. Kanazawa, A. Okada, E. Igarashi, M. Higaki, T. Miyabe, T. Sano, R. Nishimura, J. Chromatography A, 1031, (2004) 213-218. 